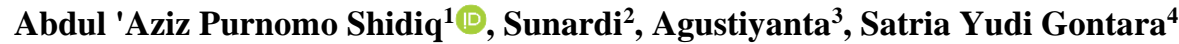 Sports Faculty Sebelas Maret University Surakarta, Indonesia
}

\section{Adequacy of the basic handball techniques training}

\begin{abstract}
The basic handball technique training for beginners must be in accordance with the physical condition of the player. The intensity and frequency of the exercises are determined precisely so that the exercises are effective and efficient. This research focuses on appropriate training programs so that optimal training results. The target of this research is in the form of training instruments / training programs and research results are published in reputable international journals. The research method used is research and development. The product developed in this research and development refers to the training program that is expected to be a reference in the implementation of basic handball technical training for beginners. From the results of the study, the training program for handball games has a validity of 0.87 so that it can be concluded that the training program for the adequacy of the basic handball technique is effectively used for the beginner athlete training program. Besides that, the training program for the adequacy of basic handball techniques is very much in accordance with the characteristics, growth, development of learners and beginner athletes and is able to make students easier to learn the basic techniques of handball games. The results of the measurement exercise, passing exercises performed 126 times, dribbling exercises performed 238 times, and shooting exercises were carried out 125 times.
\end{abstract}

Keywords: training program, basic training, handball

\section{Introduction}

Handballs are the focus of attention recently in Surakarta and surrounding areas. The game consists of 2 teams, each team consisting of 7 people into a game that attracts the attention of the general public and students in particular because it is easy to do. The purpose of this game is to score as many points as possible against the opponent's goal with the allotted time. A handball athlete must master basic techniques as a support in order to achieve optimal performance. Thus the basic technical training is important for athletes to master.

To achieve optimal results, basic technical training must be appropriate and in accordance with the athlete's physical condition. Senior athletes and junior athletes have different training programs due to different processes of adjustment,

\footnotetext{
${ }^{1}$ Abdul 'Aziz Purnomo Shidiq, e-mail: azizps@ staff.uns.ac.id, ORCID: 0000-0003-1852-1085

${ }^{2}$ Sunardi, e-mail: sunardi58@ @taff.uns.ac.id

${ }^{3}$ Agustiyanta, e-mail: agustiyanta@staff.uns.ac.id

${ }^{4}$ Satria Yudi Gontara, e-mail: yudigontara@staff.uns.ac.id
} 
needs, and experience. Excessive exercise is not recommended because it results in a decrease in the athlete's physical condition and results in less optimal athletes during the match. Adequacy of basic training becomes an important focus to be completed so that the exercises carried out are effective and efficient. Performance training is carried out at senior high schools to look for athlete seeds by conducting talent scouting and socialization as well as training for Physical Education teachers. This is done so that more and more people and students are familiar with this handball game. Handball games already have containers and championships at POMNAS level. The expectation of the Surakarta City handball committee, the championship in the city of Surakarta can be held routinely. The focus of this research is the adequacy of basic handball technical training in beginner athletes so that as early as possible with the right training program will provide optimal effects in training and physical condition. This research is expected to be a problem solver with the basic technical training needs of beginner athletes. The novelty in this study is the training program used by novice athletes in the high school student category which matches the level of maturity of motion development so that the training program is set in accordance with its portion to be able to support maximum achievement.

Exercise is a process of change towards better, including physical abilities, functional abilities of body organs, and psychological quality. Understanding of training in foreign terminology is often referred to as training, exercise, practice (Djoko Pekik Irianto. 2002: 1). From some of the terms above explained that training is the application of a plan to improve the ability to exercise that contains theoretical and practical material. Exercise is the main tool in the daily training process to improve the quality of the functioning of the human organ system. Practice is an activity to improve sports skills (skills) by using various equipment according to the goals and needs of the sport branches (Sukadiyanto. 2002: 5-6). Physical activity is an activity that can be measured and can be carried out by everyone examined by Leonardo (2013), Dowling \& Flintoff (2015), Belran, et al. (2016).

According Sukadiyanto (2011: 1) states exercise is a process of change for the better, namely to improve the physical quality, functional abilities of the body, and the psychological quality of the trainee. Therefore training is an important part for an athlete. According Sukadiyanto (2011: 7) states the main task in training is to explore, compile, and develop the concept of training by combining practical experience and scientific approaches, so that the process of practicing training can take place precisely, quickly, effectively, and efficiently. For this reason the training process is always characterized by: 1) A process to achieve a better level of ability to exercise, which requires a certain amount of time (phasing) and requires proper and careful planning. 2) The process of training must be regular and progressive in nature. Regularly means that the training must be carried out in a steady, advanced, and continuous manner. While the intention is that the training material is given from easy to difficult, from simple to more difficult (complex), and from mild to heavier. 3) Every time one face to face (one session or one unit of training) must have goals and objectives. 4) The training material must contain theoretical and practical material, so that the understanding and mastery of skills become permanent training. 5) Using a particular method, which is the most effective way that is planned in stages by taking into account the difficulty factor, the complexity of the motion, and the emphasis on 
the target practice. In this case the use of the program to support the exercise using the learning modules that have been provided is examined by Silk, et al. (2014), Neill, et al (2014). Stefansen, et al. (2016).

Training Components According to Sukadiyanto (2011: 25) states, the training component is a key or important thing that must be considered in determining the dose and training load. In addition, the training component as a benchmark and benchmark is very decisive to achieve whether or not a goal is achieved in the training objectives that have been prepared and implemented.

Handball is a team sport where two teams of 7 players each try to put a ball into the opponent's goal. Muhlisin \& Joko (2016: 2). Handball games have a number of basic techniques that need to be learned. Therefore a handball player must have good technique. Players must be able to start running quickly, have agility (agility) can catch the ball steadily, throwing (passing) the ball on target. In addition, players must have good body coordination and master some techniques of firing the ball at the opponent's goal.

In outline, the basic techniques of handball game consist of: (1) Dribbling is a basic technique that is quite difficult because it requires high hand-eye coordination and observant when reflecting the ball so that the ball resists precisely and remains in the mastery of the dribbler. One of the obstacles commonly experienced by players who play on an open field (dribbling) in dribbling is the uneven surface of the field so that it increases the level of difficulty in carrying out the dribbling because the direction of the reflection of the ball will depend on the direction coming from the ball to the ground. Thus, the reflection between dribbling on the spot and dribbling while moving requires adjusting body style and posture. Dribbing basically consists of two parts, namely straight dribbling and cross dribbling. Special cross dribbling requires high agility, skill and high hand-eye coordination. (2) Passing is one of the techniques in handball games. Passing a ball is a systematic collaborative activity on a team to look for opportunities to score goals. Passing ball between players is done in an effort to build an attack on the opponent's defense, in order to produce a goal. Passing is essentially divided into two parts, namely passing with two hands and passing with one hand. (3) Catching the Ball requires a posture that is adjusted to the coming pitch. Catching the ball requires good eye and hand coordination so that the direction and time when catching the ball can be in accordance with the direction the ball is coming. Catching the ball also requires continuous concentration and speed to get a good catch that will affect the next movement. (4) Shoot the ball is a form of throwing motion intended to put the ball into the goal. Thus, the motion to shoot the ball must be directed. Players can determine the direction of the shot carried out with sufficient practice. Athletes who rarely practice will have difficulty when shooting the ball and the ball fired will not be directed according to the wishes of the athlete. In contrast to athletes who do training seriously and regularly. The results obtained will be in accordance with what was trained before. The concept of training and basic techniques of handball are combined into an appropriate training program so that the athlete's training is regular and systematic so that results can be achieved optimally. Sufficient training for beginner athletes is given so that the exercises carried out efficiently to prepare for a competition. 


\section{Methodology}

This type of research is a research and development. Sukmadinata (2010, p.164) states that research development or often referred to as research and development (R\&D) is a process or steps to develop a new product or improve existing products, which can be accounted for. This development research classifies the test subjects into two, namely: The small group trial subjects in this development study used 20 class $\mathrm{X}$ students of SMA Negeri 4 Surakarta. The large group trial subjects in this research development used 20 class X students of SMK Negeri 2 Surakarta, 20 class X students of SMK Negeri 5 Surakarta. The effectiveness test subjects in this development research used 20 grade X students of SMA Negeri 6 Surakarta.

The technique of determining the subject of trials in this research development is the simple random sampling method. According to Sugiyono (2009: p.218) simple random sampling is a sampling technique or subject that provides equal opportunities for each element (member) of the population to be elected as a sample or subject member. The development procedure in this study was adapted from the development model according to Sugiyono (2009, p.409) covering ten steps that must be implemented, namely: (1) information gathering, (2) planning, (3) developing initial products, (4) initial trials, (5) revisions to compile main products, (6) major field trials, (7) revisions to compile operational products, (8) operational product trials, (9) final product revisions, and (10) dissemination and implementation of development products. The results of the dissemination product can be implemented widely by educators, high school teachers and education activists according to the age and character of students. Dwiyoga (2004: p.6) states that each researcher can choose and determine the most appropriate step for the development of research carried out based on the conditions and obstacles encountered. Based on this opinion in this research the simplification of the development procedure is carried out in accordance with the constraints and conditions in the study.

The steps are adapted into eight draft development research procedures, namely: (1) gathering information in the field, (2) analyzing the products to be developed, (3) developing initial products, (4) conducting expert validation, (5) conducting small-scale trials and revisions, (6) conducting large-scale trials and revisions, (7) making final products, and (8) conducting effectiveness tests.

The effectiveness test is carried out to determine the effectiveness of the training program for the adequacy of the basic technique of the handball. This final product testing is to find out that a product that has been produced is feasible and has an advantage in the level of model implementation in the field. The effectiveness test uses CAR (class action research). The steps of implementing CAR are carried out through four stages, namely: (1) action planning (2) action implementation, (3) observation and interpretation, and (4) analysis and reflection.

The data obtained in this study are qualitative data and quantitative data. Qualitative data in the form of data obtained based on the results of the validation of material experts and practitioners in the form of comments, input, or suggestions to determine the level of product viability. Quantitative data is based on data obtained from the response scores of experts and students to measure product viability, as well 
as assessment scores in CAR to determine the effectiveness of the model being developed.

The data from the results of this study were analyzed using qualitative descriptive analysis techniques and quantitative descriptive analysis techniques. Data content or material in the form of comments, suggestions from experts and students, and the observations of researchers during the trial process were analyzed descriptively qualitatively, and concluded as input to improve or revise products that have been developed. While the data in the form of scores of responses from material experts and students obtained through questionnaires were analyzed descriptively quantitatively using percentage and categorization techniques.

\section{Results and discussion}

Products produced through research and development are training programs that are suitable for beginner athletes in high school level students. Validity and reliability tests are carried out to determine the instruments used are valid and reliable. The training program for the adequacy of the basic handball technique was declared valid because the $r$ count value was 0.982 greater than $r$ table which was 0.950 . the training program for basic techniques of passing categories is very good with an average of 108.75 and a percentage of $90.63 \%$. The basic dribbling technical training program shows a very good category with an average of 113.00 and a percentage of $94.17 \%$. The ball shooting training program shows a good category with an average of 95.75 and a percentage of $79.79 \%$.

Table 1. Average Basic Training Experiments

\begin{tabular}{|c|c|c|c|}
\hline \multirow{2}{*}{} & \multicolumn{3}{|c|}{ Average Basic Training Experiments } \\
\cline { 2 - 4 } & Passing & Dribbling & Shooting \\
\hline Subject 1 & 126 & 241 & 128 \\
\hline Subject 2 & 128 & 235 & 122 \\
\hline Subject 3 & 124 & 237 & 125 \\
\hline Average & 126 & 238 & 125 \\
\hline
\end{tabular}

\section{Conclusion}

Based on the results of the study, a conclusion can be drawn that is produced an exercise program for beginner athletes with an average category that has been tested for high school students. The data has an average of 126 passing exercises for the experiment so that students can pass correctly. Dribbling exercises performed 238 trials to get good dribling results. Shooting practice is carried out 125 times to get good shooting results. Please note that the results of this study are used for students who are new to handballs for the first time. So if a handball basic technical test is performed, the student must first experiment in order to get accurate results. Furthermore, after the program is implemented, when an athlete becomes a 
professional athlete, the above treatment cannot be used as a training reference so it must be adjusted to the professional athlete's training program.

\section{References}

Beltran, J., Devis, J., Velert, C, P. (2016). The Influence of Body Discourses on Adolescents (non)participation in physical activity. Journal Sport, Education and Society, 5, 1357-3322.

Djoko, Pekik. (2002). Diktat Dasar Kepelatihan. Yogyakarta. FIK UNY.

Dowling, F., \& flintoff, A. (2015). A whitewashed curriculum? The construction of race in contemporary PE curriculum policy. Journal Sport, Education and Society. 3, 1357-3322.

Dwiyogo, W. D. (2004). Konsep penelitian dan pengembangan. Malang: Lemlit UM.

Leonardo, Z. (2013). The story of schooling: Critical race theory and the educational racial contract. Discourse: Studies in the Cultural Politics of Education, 34(4), 599-610.

Muhlisin. \& Joko. (2016). Metode \& Dasar-dasar Handball. Semarang: CV Presisi Cipta Media.

Nana Syaodih Sukmadinata. (2010). Metode Penelitian Pendidikan. Bandung: PT Remaja Rosdakarya.

Neill, M., Sproule, Horon, P. (2014). The Changing Face of Sport and Physical Education in Post-Colonial Singapore. Journal Sport Education and Society. 1, 35-56.

Silk, M., Francombe, J., \& Andrews, D. L. (2014). Slowing the social sciences of sport: On the possibilities of physical culture. Journal Sport in Society, 17(10), 1266-1289.

Stefansen, K., Smette, I., \& Strandbu, A. (2016). Understanding the Inrease in Parents Involvement in Organized Yoth Sports. Journal Sport, Education and Society. 4, 1357-3322.

Sugiyono. (2009). Metode Penelitian Kualitatif Kuantitatif dan R \& D. Bandung: Alfabeta.

Sukadiyanto. (2002). Pengantar Teori dan Metodologi Melatih Fisik. Yogyakarta: PKO FIK UNY.

Sukadiyanto. (2011). Pengantar Teori dan Metodologi Melatih Fisik, Bandung: CV Lubuk Agung. 